Local Teacher-Based Curriculum Development

\author{
Margery D. Osborne \\ Department of Curriculum and Instruction \\ University of Illinois at Urbana-Champaign \\ 1310 South $6^{\text {th }}$ Street \\ Champaign, IL 61820 \\ Heidi Buhlman Barker \\ Department of Curriculum and Instruction, \\ Department of Education, Regis University \\ 3333 Regis Boulevard
}

Denver, CO 80221

Keywords: Curriculum, Teaching, Professionalization 


\title{
Local Teacher-Based Curriculum Development
}

Margery D. Osborne and Heidi Buhlman Barker

Department of Curriculum and Instruction, University of Illinois at Urbana-Champaign

Department of Education, Regis University

\begin{abstract}
The recent history of local teacher-based curriculum development is traced and key issues such as obtaining the time, space and funding to support the teachers, obtain materials, hire substitute teachers and professional support are discussed. In particular the practice of local teacher-based curriculum development is contextualized within the professionalization of teaching movement begun in the 1980s.
\end{abstract}




\section{Local Teacher-Based Curriculum Development}

Margery D. Osborne and Heidi Buhlman Barker

Department of Curriculum and Instruction, University of Illinois at Urbana-Champaign

Department of Education, Regis University

The practice of organized, sanctioned local teacher-based curriculum development, at least in the U.S., is relatively new in public education. While the present view of teaching, especially at the elementary level, is that it is an interpretive act in which the teacher creates curriculum with each enactment, this is not the same as saying that teachers purposely and deliberatively develop curricula - lay out the scope and sequence of the things that will go on during the school year in their schools and classrooms. And most likely, in this age of national standards and outcomes followed by high-stakes achievement tests, teachers still are not asked to do this. They are, however, more and more frequently expected to develop the local, concrete and connected expressions of national or state expectations. This is important, for it is what makes the abstract "list" of national standards or outcomes relevant and connected. Its what makes the mandated curriculum teachable and educational reform, described at the policy level, actualized in the classroom.

Philosophically, local teacher-based curriculum development is a practical re-statement of a Deweyian educational principle - that to teach the abstract goals and values at the core of curriculum, it needs to be translated to the immediate and local, an activity only the classroom teacher can do. This is based on the premise that learning is local and particular and learners construct knowledge in a much more holistic and experiential fashion than can be assumed by the pre-constructed texts, worksheets, and basal readers typical of purchased curricula. To foster meaningful learning, teachers connect the differing experiences of individual learners and the abstract curriculum goals by reconstructing these goals into local curriculum. Understanding how their students think as well as what they know, teachers use an array of techniques as well as their own experientially shaped professional wisdom to build on and with the knowledge, ways of knowing and worldviews of their students. This more complex approach to teaching requires that teachers combine deep knowledge of subject matter and a wide repertoire of teaching strategies with intimate knowledge of students' growth, experience, and development. The move to acknowledge this and organize this process began in the U.S. with the post-mortems conducted around the failures of the teacher-proofed curriculum of the 1960s and 1970s. In Great Britain it crystallized in the work of Lawrence Stenhouse (1980). 


\section{History and the Professionalization of Teaching}

The 1960s and 1970s were years in which the greatest effort in the U.S. and abroad were made to reform education through curriculum materials. These curriculum materials were produced by national organizations with unprecedented levels of funding (Darling-Hammond, 1996). The curriculum committees were comprised of experts from the disciplinary fields (as well as the occasional teacher) (Bruner, 1960/1977). Holding to the curriculum model of researchers such as Tyler (1949), educational "experiences" were selected and developed to attain objectives agreed upon by the expert curriculum committees. The effects of teachers translating the curriculumwith the assumption this meant diminishing the curriculum — was purposely side-stepped through policy statements warning administrators to watch for and correct this tendency, extensive teacher manuals on implementation, workshops aimed at inducting teachers into "correct" ways of teaching the materials and even scripted lessons. The results, whether disciplinary or equity driven, were not very positive, especially measured relative to the goals of the curriculum developers (for example, Stake and Easley 1978). In retrospect this failure was attributed to the lack of acknowledgment of the role of the teacher in both forming the curriculum and in actualizing it. This set the stage for the present environment of organized local teacher-based curriculum development.

The situation of education in the 1980s in the U.S. was shaped by two important sets of policy reports, the publication of $A$ Nation at Risk in 1983 and the publications by the Holmes Group, the Carnegie Task Force of Teaching as a Profession as well as other policy groups and teacher unions arguing for an acknowledgement of teaching as a unique professional activity with consequent public professionalization of teaching as a career. A Nation at Risk in the U.S. and similar studies and documents in other countries argued for an increase in academic standards and rigor in public schools. This initiated the development and implementation of both national and state disciplinary standards. Unlike A Nation at Risk, that called for greater external determinates of school curriculum, the Holmes Group and other reports on professionalization of teaching argued that the improvement of schools would come through increasing the status and power of classroom teachers and by decentralizing school decision making. From then until the recent policies such as No Child Left Behind (2001) came into play, the call was for the empowerment of teachers to participate in a central way in the determination of school goals and policies, and to exercise their professional judgment about the content of the curriculum and means of instruction. 
To reconstruct teaching as a formal profession analogous to other people-helping professions such as social work or nursing (Stronach et al, 2002) meant codifying the responsibilities of the teacher and constructing a framework for enabling and rewarding these professional activities. Most efforts in this regard focused upon pedagogy and the resulting reward structures and professional certifications such as National Board Certification in the U.S. have endured. Similarly the recent manifestations of local teacher-based curriculum development are linked to arguments around the professionalization of teachers. In other words defining curriculum making as a teacher province has political overtones. The groundbreaking book Teachers as Curriculum Planners: Narratives of Experience By F. Michael Connelly and Jean Clandinin published in 1988, argued that curriculum development and planning were fundamental activities for teachers. Since then images of local teachers gathered together to write curriculum has become central to most current visions of the implementation of reforms of education in school whether driven by disciplinary questions or those of social justice.

\section{Discussion and Issues}

This has fallen out in a number of ways, however, and as an example we describe two contrasting school districts we have worked with during the later 1980s through the 1990s as part of a larger set of studies on teacher-based curriculum development. In one, town " $\mathrm{X}$ ", with a heritage of libertarianism, until very recently had no curriculum, or rather there were no books or districtwide programmed course of study. Instead there were lists of things each teacher was expected to cover and finally there were the state achievement tests to make sure they did. Each teacher was responsible for coming up with materials, activities, lesson plans, approaches, etc-whatever was needed to achieve the goals. In town "Y", which is next door to town "X", there was a much more top-down approach. Here there were the same lists of goals and outcomes but the administration organized teams of teachers to either evaluate commercial curriculum units and purchase them or to develop curriculum themselves. For example in science in the late 80 s the teachers decided to develop their own curriculum. To do this they applied for grants to fund an infrastructure to support curriculum writing. They visited other school districts engaged in similar endeavors. They developed a model of what they thought the curriculum should work like and a plan to actualize it. They applied for more grants to fund the teachers writing the curriculum and to do inservice work with the other teachers in the district so they would know how to teach it.

Arguably what we have described are two models of the profession. In town " $\mathrm{X}$," the teacher is assumed the professional and the definition of the professional is that they are able to construct 
curriculum. In the second example there is a systemic tie of curriculum development to professional development. In other words the professional definition of the teacher isn't that they know how to construct curriculum. Rather they get smart and figure out ways to get smarter and they do this together and this becomes school and professional development.

The distressing thing is that often and in their varied ways these processes duplicated the development and implementation years of the 1950s-1970s. For example, town "Y" in recent years, when professional staff development funds from the state ran low, ended up using their science curriculum like the older teacher-proof materials of the 1970s. In town " $X$ " enterprising teachers formed affinity groups, so teachers with an interest in social studies, as an example, got together and began study groups developing curricular materials and discussing pedagogical issues. These were wonderful where they existed but often teachers who didn't or couldn't join these groups ended up secretly hoarding ancient textbooks and guiltily teaching from those. The net effect was to reinforce the professionality of some but to disempower and isolate others.

Both descriptions illustrate the good and the bad of local school-based curriculum development. In the process of curriculum development, teachers translated the abstractions of policy and standards to the particular and teachable. Moreover, this development role required teachers to reinvent themselves professionally. They became, in practical terms, individuals that reinterpreted curricular ideas, adapting them to suit local circumstances and becoming curriculum developers (Schwab in Westbury and Wilkoff, 1978). Malcolm Skilbeck's (1984) model of school-based curriculum development describes a form of 'situational analysis' as an important element in the process whereby teachers redesign the curricula they teach. This is central in current manifestations of local school-based curriculum development and how it is placed in school reform enactment. The net outcome of these processes in the 1990s was to assert the role of teachers in the development of distinctive school profiles and the institutionalization of collectively driven school improvement plans_-both still customs within American schools today.

This professional role in which teachers are engaging in interpretative acts of curriculum construction and are asking themselves and their peers to recreate their practice is full of conflicts, however. These roles often involve assuming grassroots leadership functions frequently in tension with existing hierarchies and relationships within a school. Teachers assume agency in constructing their interpretations of a reform, and this agency is responsive to and shaped by their 
interactions with others. In the process reform is interpretative with teachers not as sole reform actors, but relationally positioned in the process of enacting reform. As an example we describe another school district we have had a long-term relationship with, "Z." This vignette is from a series of larger studies conducted by the authors (Barker, 2000; Leander and Osborne, 2008).

In district " $Z$ " the teachers in the science committee came to us to help them rewrite their science curriculum. After they outlined their needs we formulated a threefold approach-on-going support while they developed and chose curricular materials, a summer science "camp" in which teachers worked out pedagogical issues, classroom support while the teachers piloted the units.

The members of the science committee took the lead. The first time that grade level groups met in the second year of the project they spent at least half of an in-service day discussing and going through the national and state standards applicable to each grade level. All of the sets of standards state that learning science should be a process-oriented experience, promoting science content through inquiry skills and that the focus should be on the doing and discussing rather than on memorizing specific science content and facts. But, instead of seeing that as a powerful reason to make reforms, many of the teachers questioned whether these entities (the standards and the curriculum and pedagogy) were aligned and whether or not curriculum based on them would achieve good test scores.

David was not an original member of the science committee and he did not participate in the summer science camp, but he did come to the first of the grade level meetings for third grade. Part of the reason for a change in curriculum and the discussion of the science curriculum, according to David, was a lack of communication between grade levels and within grade levels about what science was taught. The following exchange took place between David and other teachers at the grade level meeting.

David: So, there are only four unit topics to be covered the entire year? Do you see them lasting a full nine weeks each?

Jennie: Well, there is so much material and the kids are loving it. I'm hoping that I can get it all done before I have to move on.

Gordon (who was the administrator in charge of curriculum for the district): That's the mentality that we have to get away from. Now it's time for Science. Now it's time for Social Studies. We need to start thinking of the learning as a whole. 
David: That's easy for you to say, but I switch with another teacher and am locked into a schedule. I suppose we could combine classes and I teach science every day for a half hour. Will there be enough to last a whole nine weeks?

Liz: It's a different approach. Instead of a smattering of subjects, we are going in depth on a few.

David: So it's like if you teach multiplication in third grade then you don't get it again until it comes up in high school? Once the subjects are taught they aren't covered again.

Liz: But now we are teaching things that aren't appropriate for some grade levels. This scope and sequence looks at the grade levels and it isn't the only time a subject is taught.

The teachers that answered David had already been piloting some of the units in their classrooms or had been a part of the summer science camp where they had tried out the teaching. David had had no experience with the new curriculum, but was concerned about how it would impact the way his classroom and the science curriculum he had been teaching worked. The new program directly challenged the way that he perceived his success in teaching was achieved.

David wanted to make sure that his goals for teaching met the expectations of his community, the state, his administrators, and most importantly that they delivered what he believed to be good science teaching. He wanted to "know" that his students came away from his classroom ready to go to fourth grade, ready to pass the standardized tests, and ready to understand some basic science facts and concepts. David was not convinced that the new curriculum would meet these expectations. At one point he made a list of the topics covered on the tests to show us. "Think about it. If the tests are in early spring that means my class will have only covered two maybe three topics. That's not what the tests expect that we've covered." David was worried about the test scores and concerned about the amount of content, vocabulary and time spent on each unit. He was also concerned about the bigger picture of the topics taught and the depth of the topics taught across the grade levels.

The curriculum development and dissemination as well as the distribution of leadership roles amongst the teachers in district " $Z$ " did not occur smoothly or without conflict. To the inherent difficulties grassroots leaders in schools face, we would add the question of dissemination and enactment. There are personal and professional tensions between teachers and those actually engaged in curriculum development--hierarchies exist within the teaching community and school 
and often curriculum developers come into conflict with these and even when this is not so, there is a tradition of individuality in classroom teaching that school-based curriculum development comes confronts. Sarason's mapping of school cultures, including his important analyses of the sociopolitical positions of teachers (1982), critically foregrounds the tensions teachers face within schools including the ones we are describing. Sarason and others have also noted how it is just these tensions which impede the evolution and change of curriculum and pedagogy.

\section{Summary}

This story and the previous highlight many of the conflicts and concerns teachers feel while engaged in local teacher-based curriculum development. Key issues include obtaining the time, space and funding to support the teachers, obtain materials, hire substitute teachers and professional support. When engaged in the 'experimental' (Stenhouse, 1980) portion of curriculum development in which new units and their pedagogies are tried out, teachers need classroom support and spaces of relaxed accountability so that they can become risk-takers. School wide dissemination of teacher-developed curricula is also full of tensions and role shifts. Support structures are rarely in place for this portion of the process. Finally professional development for teachers involved in curriculum development currently takes the form of programs such as Learning by Design (Wiggens and McTighe, 2002). This might possibly include a component of presentation of research into making the 'practical' (Schwab, 1978) practical that goes beyond the action research programs currently in place.

\section{Bibliography}

Barker, H. B. (2000). Teachers and the reform of elementary science: Stories of conversation and personal process. Charlotte NC: Information Age Publishing.

Bruner, J. ( 1960/1977). The process of education. Cambridge, MA: Harvard University Press.

Connelly, M., and J. Clandinin. (1988) Teachers as curriculum planners: Narratives of experience. New York: Teachers College Press.

Darling-Hammond, L. (1996) The Right to Learn and the Advancement of Teaching: Research, Policy, and Practice for Democratic Education. Educational Researcher 25, 5-17.

The Holmes Group (1986) Tomorrow's teachers. East Lansing, Mich.: Holmes Group.

Leander, K.M. and Osborne, M.D. (2008). Complex positioning: Teachers as agents of curricular and pedagogical reform. Journal of Curriculum Studies, 40, 23-46.

National Commission on Excellence in Education (1983) A nation at risk: The imperative for educational reform. Washington D.C.: U.S. Government Printing Office. 
No Child Left Behind Act (2001). Retrieved July 152007 from the No Child Left Behind Act on the United States Department of Education Website: http://www.ed.gov/policy/elsec/leg/esea02/index.html

Sarason, S. (1982) The culture of school and the problem of change. Boston: Allyn and Bacon.

Skilbeck, M. (1984) School-based curriculum development. ( London, Harper and Row), 232234.

Stake, R., and Easley, J. (Eds.). (1978). Case studies in science education. (Vol. 1 and 2). Urbana, Il: Center for Instructional Research and Curriculum Evaluation.

Stenhouse, L. (1980) 'Curriculum research and the art of the teacher', Curriculum 1, 40-4.

Stronach, I., Corbin, B., McNamara, O., Stark, S., Warne, T., (2002) Towards an uncertain politics of professionalism: Teacher and nurse identities in flux. Journal of Education Policy 17 109-138.

Tyler, R. W. (1949) Basic principles of curriculum and instruction. Chicago: University of Chicago Press.

Westbury, I. and Wilkoff, N. J. (eds.) (1978) Joseph J. Schwab, Science, liberal education, and curriculum: Selected essays. Chicago: University of Chicago Press.

Wiggins, G. P., and McTighe, J. (1998). Understanding by design. Alexandria, VA: Association for Supervision and Curriculum Development.

\section{Further Reading}

Carnegie task Force on Teaching as a Profession (1986) Teaching as a profession, a nation prepared: Teachers for the 21st century. New York: Carnegie Forum on Education and the Economy.

Ruddock, J. and Hopkins, D. (eds.) (1985). Research as a basis for teaching: Readings from the work of Lawrence Stenhouse. Portsmouth, N.H.: Heineman.

Darling-Hammond, L. and Bransford, J. (eds.) (2005). Preparing teachers for a changing world: What teachers should learn and be able to do. San Francisco, CA : Jossey-Bass. 